\title{
Reproductive ecology of the invader species gekkonid lizard Hemidactylus mabouia in an area of southeastern Brazil
}

\author{
Luciano A. Anjos \& Carlos Frederico D. Rocha
}

Setor de Ecologia, Instituto de Biologia Roberto Alcântara Gomes, Universidade do Estado do Rio de Janeiro, CEP 20550-013 Rio de Janeiro, RJ, Brasil. (mabuyasp@yahoo.com.br)

\begin{abstract}
Hemidactylus mabouia Moreau de Jonnés, 1818 is a "fixed" clutch size exotic species well established in Brazil. In this paper we investigate some reproductive strategies adopted to minimize the costs of invariant clutch size to this invader species living in an environment with marked climatic seasonality in Southeastern Brazil (22 $\left.56^{\prime} \mathrm{S} ; 46^{\circ} 55^{\prime} \mathrm{W}\right)$. The study was carried out from April 2002 to March 2003. Females and males attain maturity at $47.9 \mathrm{~mm}$ and $46.9 \mathrm{~mm}$ SVL, respectively. Larger females tended to produce larger eggs. The reproduction occurred throughout the year, but only at the wet season the females increase the clutch frequency. There was a significant variation in mean testis volume among the months throughout the year and the largest means were recorded between August and December. Maternal investment on egg size, increase on clutch frequency and seasonal increase on testis volume can represent important reproductive strategies of this invader species living in an non-urban habitat whit climatic seasonality (dry and cold weather season).
\end{abstract}

KEYWORDS. Hemidactylus, exotic species, reproduction, egg size relationships.

RESUMO. Ecologia reprodutiva da espécie de lagarto gekkonídeo invasora Hemidactylus mabouia em uma área do sudeste do Brasil. Hemidactylus mabouia Moreau de Jonnés, 1818 é uma espécie exótica, com tamanho fixo de ninhada e bem estabelecida no Brasil. Neste estudo foram investigadas algumas estratégias reprodutivas adotadas no sentido de minimizar os custos do tamanho fixo de ninhada nesta população que vive em uma região onde há uma marcada sazonalidade climática. O estudo foi realizado entre abril de 2002 e março de 2003 em Valinhos (22 $56^{\prime} \mathrm{S}$; $46^{\circ} 55^{\prime} \mathrm{W}$; sudeste do Brasil). Os resultados indicaram que as fêmeas atingem a maturidade sexual com $47,9 \mathrm{~mm}$ enquanto que os machos com $46,9 \mathrm{~mm}$. As fêmeas maiores tendem a produzir ovos maiores. A reprodução ocorre ao longo do ano todo, mas somente durante a estação úmida as fêmeas aumentam a freqüência reprodutiva. O tamanho médio dos testículos sofre uma variação ao longo do ano e as maiores médias foram registradas entre os meses de agosto e dezembro. Investimento maternal no tamanho do ovo, aumento na freqüência reprodutiva e aumento sazonal no volume médio dos testículos podem representar uma importante estratégia reprodutiva desta espécie invasora que habita um campo ruderal com sazonalidade climática marcada (estação fria e seca bem definida).

PALAVRAS-CHAVE. Hemidactylus, espécie exótica, reprodução, tamanho de ovo.

The total reproductive output of an individual during its reproductive season is a function of offspring number, offspring size, and clutch frequency. As an individual has a finite amount of energy to spend on reproduction, the female must do a trade-off among these reproductive parameters (SELCER, 1990). Some lizard species of different families (e. g. Gekkonidae, Gymnophtalmidae and Polychrotidae) exhibit "fixed" clutch size, producing always one or two eggs per clutch (ANDREws \& RAND, 1974; VitT, 1986; Selcer, 1990). The "fixed" clutch size can limit these species in size and mass of offspring and/or frequency of clutches (SELCER, 1990). Lizards presenting a "fixed" clutch size tend to maximize their reproductive outcome by increasing the frequency of clutches, increasing egg size, or investing in vitellogenic nutrients (ANDREWS \& RAND, 1974; VITT, 1986; Doughty, 1997; SELCER, 1990).

Hemidactylus mabouia Moreau de Jonnès, 1818 is a successful colonizer (MeshaKa, 2000; Meshaka et al., 1994) well established in Brazil (VANZOLINI et al., 1980) and, nowadays it is quickly colonizing the North American Continent (LAwson et al., 1991; ButTERFIELD et al., 1993; Meshaka et al., 1994; MeshaKa, 2000). A well-established population of $H$. mabouia was found living in an outcrops non-urban environment of Valinhos municipality (22 $56^{\prime}$ 'S; $\left.46^{\circ} 55^{\prime} \mathrm{W}\right)$, in state of São Paulo, Brazil. The knowledge about the reproductive process of an invasive species is the key to understand its success as an invader, as well as to control established populations (WHITTIER \& Limpus, 1996). Hemidactylus mabouia has a "fixed" clutch size, producing two eggs per clutch, with a yearround reproduction (VITT, 1986; MESHAKA, 1994; but see Bonfiglio et al., 2005). Some authors point out that $H$. mabouia has a high fertility (Bock, 1996; MEshaKA et al., 1994); nevertheless there is no accurate data on reproductive frequency or longevity for this invader species. In this paper we investigate some reproductive aspects, such as extension of the reproductive period, minimum size at maturity, frequency of clutches and parental investment of a population living in a non-urban area (Valinhos) with marked climatic seasonality in southeastern Brazil.

\section{MATERIAL AND METHODS}

This study was carried out between April 2002 and March 2003 in a grassland area in Valinhos municipality (22 $56^{\circ}$ 'S; 46 $\left.55^{\circ} \mathrm{W}\right)$, state of São Paulo, southeastern Brazil, at an elevation of approximately $700 \mathrm{~m}$. The area has abundant granite boulders surrounded by grassy and shrubby vegetation. Rainy season occurs from October to March and the dry one from April to September; the mean annual temperature $( \pm \mathrm{sd})$ and total annual rainfall are $20.7 \pm 2.2^{\circ} \mathrm{C}$ and $1,379 \mathrm{~mm}$, respectively 
(VAN SLuYs et al., 1994). During the period of this study, rainfall totaled $230 \mathrm{~mm}$ in the dry season and $1,047 \mathrm{~mm}$ in the wet season [all climatic data were obtained from the Centro de Pesquisas em Agricultura (CEPAGRI) of the Universidade Estadual de Campinas] (Fig. 1).

Lizards were collected with a noose or by hand. Immediately after capture, each lizard was transferred to a plastic sac containing cotton embedded in ether, in order to euthanasia them. We collected 295 lizards, of which 88 were adult males, 88 adult females, and 119 juveniles.

In the laboratory, lizards were fixed with $10 \%$ formalin solution and stored at $70 \%$ alcohol solution. After that, they were dissected and their gonads were removed for posterior analysis. In females we measured the longer and the shorter length of the eggs in each oviduct, and, when present, the largest follicle in each ovary, registering the condition of those vitellogenic follicles [enlarged yolked ovarian follicles are yellow colored, and this coloration indicate the secondary vitellogenic follicle condition, according to BlANCO \& Acosta (1998)]. The criterion used to determine the minimum size of an adult female was the smallest female containing enlarged yolked ovarian follicles (diameter $\geq 1.9 \mathrm{~mm}$ ). In males, we measured the longer and the shorter length of the largest testis. All measurements were taken with a caliper (at the precision of $0.01 \mathrm{~mm}$ ). To determine the minimum size of adult males, slides were made of both testis and epididymis of each male. The gonads were embedded in paraffin, sectioned in transversal axis at $5 \mu \mathrm{m}$, and stained with hematoxylineosin. Males containing sperm in epididymis were considered adult.

In the field, upon the sand soil and covered by grass that grows besides rocky walls we collected three clutches, with two eggs each. The first two clutches were collected on August 2002 and the third clutch was collected on September 2002. Clutches were carefully removed and stored in a plastic recipient containing a small amount of substrate (sandy soil) from the site where the eggs were removed. Clutches were taken to the laboratory and kept in similar conditions of temperature and humidity to those encountered in the field, until they hatched. During these period the monthly mean temperature, at the laboratory, ranged from $22.4^{\circ} \mathrm{C}$ to $26.5^{\circ} \mathrm{C}$ (similar values to that registered at the field (Fig. 1)). The collection and maintenance of eggs in captivity aimed to development and hatching of eggs in order to obtain some information about the size of newborns on this population studied.

For estimation of testis volume $\left(\mathrm{mm}^{3}\right)$ we used the ellipsoid formula: $V=4 / 3 \times \pi \times(L / 2) \times(W / 2)^{2}$

where, $\mathrm{V}=$ volume, $\mathrm{L}=$ higher length and $\mathrm{W}=$ lesser length. We used a regression analysis to evaluate the effect of lizard body size (snout-vent length) on testis/ follicle or egg volume. When the data set did not fit the normal distribution, or were a heterocedastic, data were log-transformed (ZAR, 1999). Residual analysis between reproductive structures (i.e. testis, follicle and egg volumes) and lizard size (snout-vent length) was also performed (ZAR, 1999). An ANOVA was performed to test whether there was a significant difference between the residuals of testis volume throughout the year (ZAR, 1999).
We used an a posteriori test, least square deviation (LSD), to investigate in which months the mean of residuals was different from the other ones (ZAR, 1999). We also used ANOVA to test for differences on the residuals of egg volume between dry and wet seasons. The proportion of gravid females in the wet and the dry seasons was analyzed by a $Z$ test for proportion (ZAR, 1999).

\section{RESULTS}

The SVL of the smallest male with sperm in testis or epididymis was $46.9 \mathrm{~mm}$. The mean adult male SVL was $56.7 \pm 5.0 \mathrm{~mm}$ (range $=46.9-68.2 \mathrm{~mm}, \mathrm{n}=88)$. The SVL of the smallest adult female was $47.9 \mathrm{~mm}$. Mean adult female SVL was $56.6 \pm 5.2 \mathrm{~mm}$ (range $=47.9-67.2 \mathrm{~mm}, \mathrm{n}=88$ ). There was no significant difference $(t=-0.231 ; \mathrm{df}=173 ; \mathrm{p}=$ 0.818 ) in the mean SVL between adult males and adult females.

Females containing oviductal eggs were collected in almost every month of the studied period (Fig. 2) and

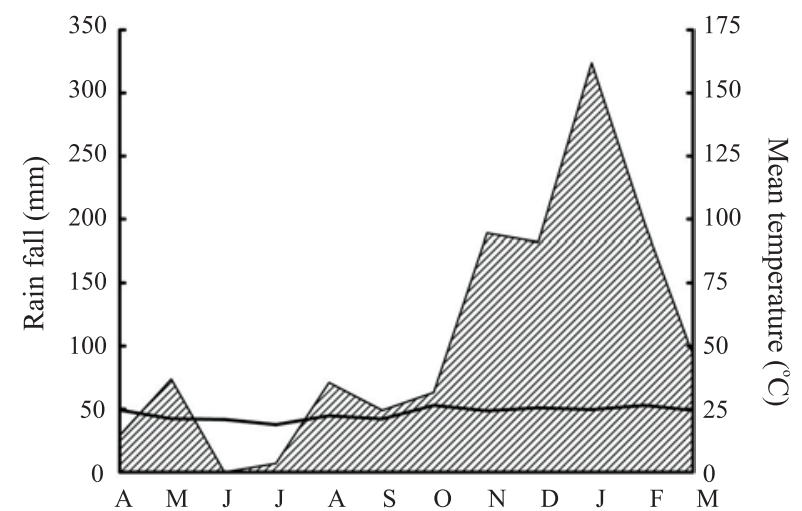

Fig. 1. Monthly mean temperature (in ${ }^{\circ} \mathrm{C}$, solid black line) and rainfall (in $\mathrm{mm}$, hachured area) in Campinas-Valinhos region, southeastern Brazil from April 2002 to March 2003. Data were provided by Centro de Pesquisa em Agricultura (CEPAGRI) of the Universidade Estadual de Campinas.

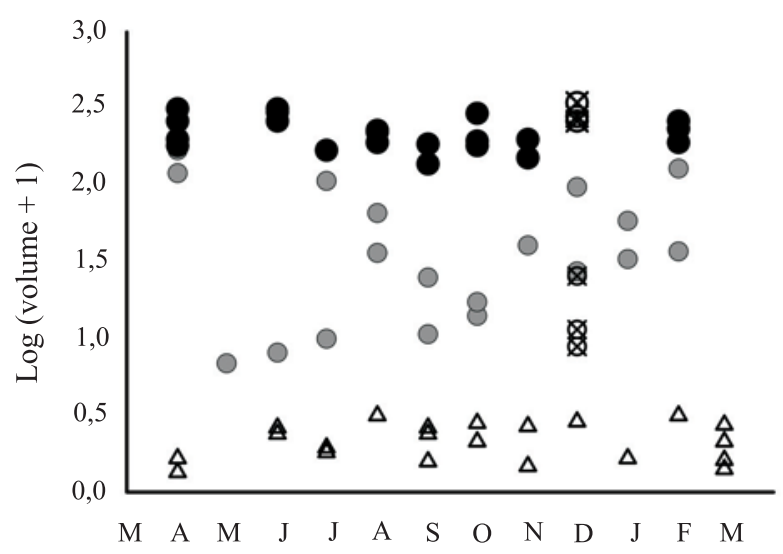

Fig. 2. Log-transformed volumes of larger non-vitellogenic ovarian follicles (triangles), larger enlarged yolked ovarian follicles (grey circles), and larger oviductal eggs (solid circles) of females Hemidactylus mabouia Moreau de Jonnés, 1818 captured in Valinhos, southeastern Brazil, between April 2002 and March 2003. Open circles marked with $\mathrm{X}$ represent the three females with both oviductal eggs and enlarged yolked follicles. 
in December 2002 we recorded three females containing both oviductal eggs and enlarged yolked follicles (Fig. 2). There was no significant difference in the proportion of gravid females captured between dry $(27.7 \%)$ and wet $(26.8 \%)$ seasons ( $Z$-test: $\left.Z_{C}=0.52 ; d f=1 ; p=0.603\right)$.

Female body size affected egg volume $\left(R^{2}=0.57\right.$; $\mathrm{F}_{1,20}=26.57$; $<<0.001 ;$ Fig. 3). Nevertheless the maternal investment in volume of oviductal eggs, after removed the female size, did not differ between wet and dry seasons (ANOVA; $F_{1,22}=0.95 ; p=0.66$; Fig. 4).

With regard to males, there was a significant variation in mean testis volume (independent of male size) among the months throughout the year (ANOVA; $\mathrm{F}_{11,76}=$ $3.99 ; \mathrm{p}<0.001)$. The largest testes were recorded between August and December 2002 (Fig. 5).

The viability on development and hatching of eggs collected at the field was $100 \%$, and the incubation period ranged between 22 and 68 days. The hatchlings' mean SVL for the each one of the three clutches were

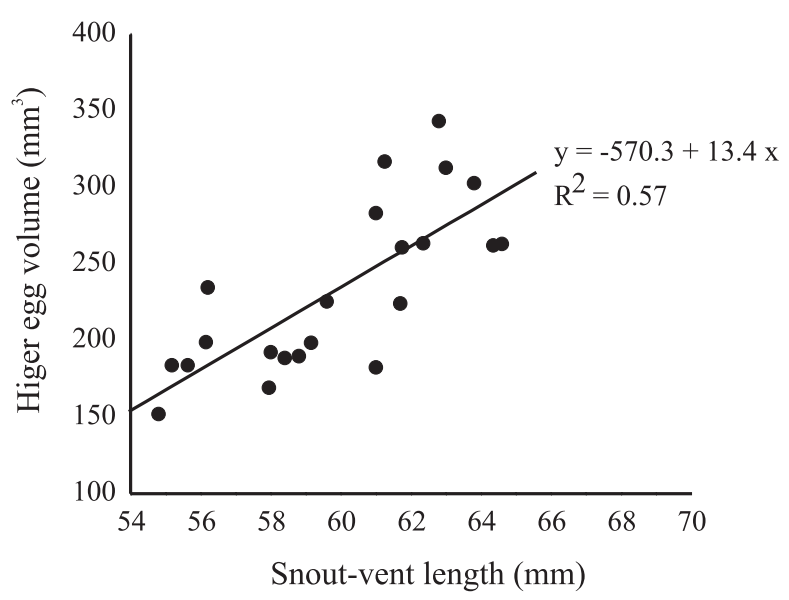

Fig. 3. Relationship between Snout-vent length $(\mathrm{mm})$ and larger egg volume of female Hemidactylus mabouia Moreau de Jonnés, 1818 captured monthly at Valinhos, southeastern Brazil, between April 2002 and March $2003\left(\mathrm{R}^{2}=0.57 ; \mathrm{F}_{1,20}=\right.$ 26.57; p $<0.001)$.

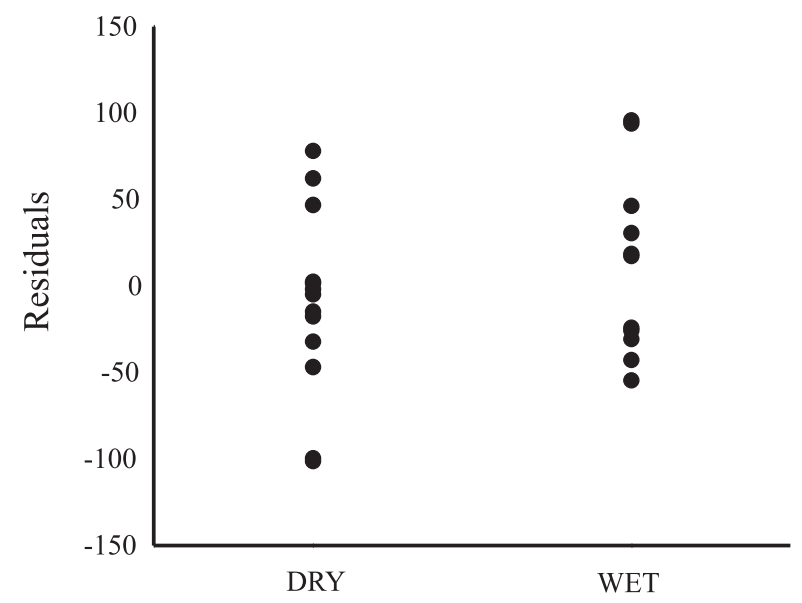

Fig. 4.Residuals of egg volume $\left(\mathrm{mm}^{3}\right)$ of Hemidactylus mabouia Moreau de Jonnés, 1818 captured during dry (April to September) and wet season (October to March) at Valinhos, southeastern Brazil $\left(\right.$ ANOVA; $\left.\mathrm{F}_{1,22}=0.945, \mathrm{p}=0.657\right)$.
$24.3 \pm 0.04 \mathrm{~mm}$ (mean mass $=0.3 \pm 0 \mathrm{~g}) ; 22.6 \pm 0.28 \mathrm{~mm}$ (mean mass $=0.23 \pm 0.04 \mathrm{~g}$ ); and $22.3 \pm 0.07 \mathrm{~mm}$ (mean mass $=0.20 \pm 0 \mathrm{~g})$. The overall hatchling SVL was 23.1 $\pm 1.0 \mathrm{~mm}$ (range $=22.2-24.4 \mathrm{~mm})$ and overall mean hatchling mass was $0.24 \pm 0.05 \mathrm{~g}$ ( range $=0.2-0.3 \mathrm{~g}$ ). We collected juveniles with body size close to that of newborns hatched at the laboratory in all months throughout the year (Fig. 6).

\section{DISCUSSION}

We found no difference in the body size between males and females of the population of H. mabouia studied in Valinhos. Sexual dimorphism in body size may result from sexual selection (TRIVERS, 1972, 1976; STAMPS, 1977). If an increase on female body size influences clutch size increase and these characteristics reflect on a lizard's reproductive success, then natural selection would favor continuous growth in females, they being larger than

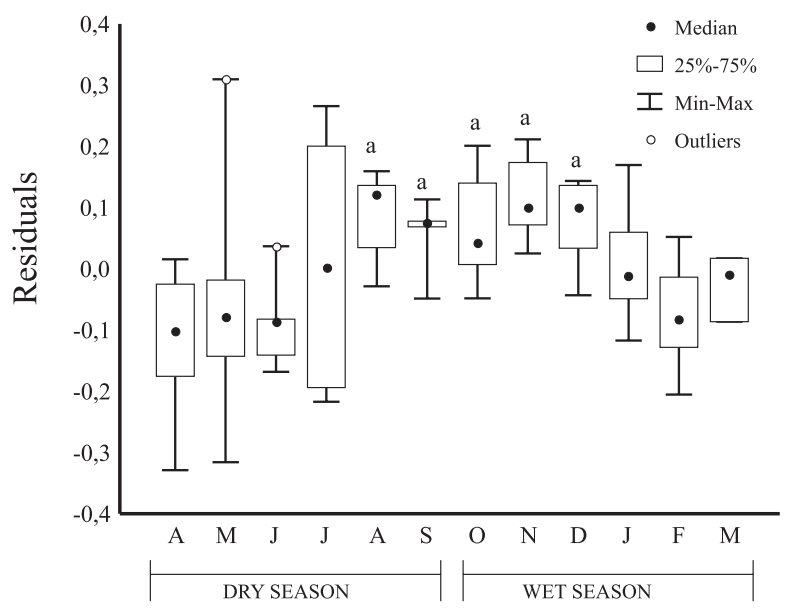

Fig. 5. Residuals of testis volume $\left(\mathrm{mm}^{3}\right)$ of adult male Hemidactylus mabouia Moreau de Jonnés, 1818 captured at Valinhos, southeastern Brazil from April 2002 to March 2003. Letter "a" denotes months with non significant differences between residuals mean value.

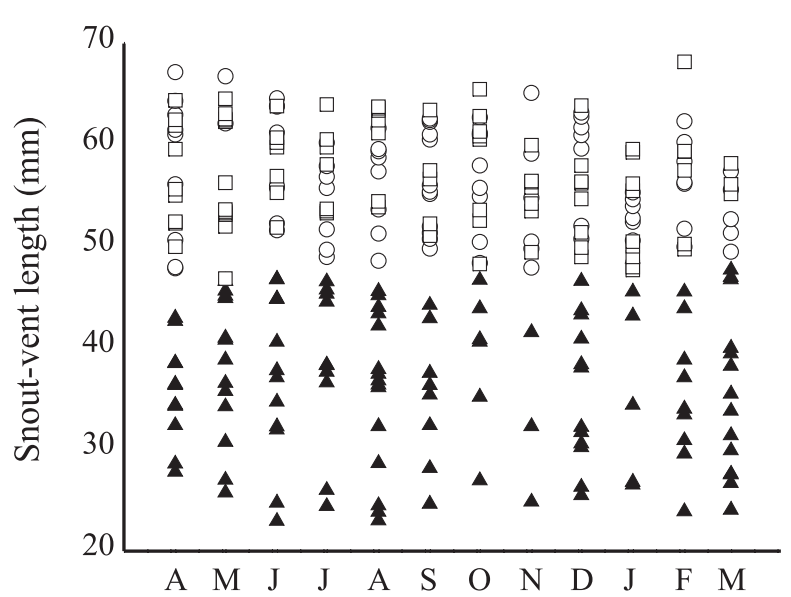

Fig. 6. Snout-vent length (mm) of Hemidactylus mabouia Moreau de Jonnés, 1818 from Valinhos. Are represented 119 juveniles ( $\mathbf{\Delta})$, 88 adult females $(\square)$ and 88 adult males (○). 
males (Trivers, 1972, 1976). Because H. mabouia has a fixed clutch size there are no evolutionary pressures to increasing female body size relative to male body size which could contribute for the lack of sexual body size differences in the species.

In lizard species with "fixed" clutch size the maximization of reproductive effort may result from two mechanisms: investment in egg size, or in clutch frequency (ANDREws \& RAND, 1974; VITT, 1986; SELCER, 1990; Doughty, 1997). Additionally, in a tropical seasonal environment, rainfall may influence clutch frequency of gekkonid lizards (SEXTON \& TURNER, 1971). As expected for this invader species, this population living in a tropical environment with rainy season presented a year-round reproduction (VITT, 1986; BUTTERFIELD et al., 1993; MeshaKa et al., 1994), although there is some evidence of a non-continuous reproduction in a population from southern Brazil (see Bonfiglio et al., 2005). But, differently from what was pointed out by MEsHaKa et al. (1994), the high reproductive frequency doesn't occur throughout the year. There was a positive correlation between female body size and egg volume in this population, unlike the results reported by VITT (1986) for a northeastern Brazilian population.

The females of the studied population do not differ in their investment in egg size and egg number between dry (April to September) and wet (October to March) season. Nevertheless, on December 2002 (middle of the wet season) all females collected $(n=3)$ had both oviductal eggs and enlarged yolked follicles, suggesting multiple clutches by each female and that during the peak of the wet season some females could be increasing clutch frequency.

Based on the number of follicles with diameters larger than 1.0mm, MeshaKa et al. (1994) assumed that $H$. mabouia could produce more than seven clutches per year. However, without information about juveniles' recruitment pattern, growth and development of ovarian follicles of this year-round reproducing gekkonid species, any assertion about the number of reproductive events become speculative. Hemidactylus brooki Gray, 1845 is a species with seasonal reproduction and in each ovarian cycle four ovarian follicles are produced, but only one attains a size large enough for ovulation (ShanbHag et al., 1998). The other three follicles degenerate and the ovarian cycle starts again with the production of new follicles (Shanbhag et al., 1998). Thus, even though $H$. mabouia might produce some follicles with diameter larger than 1.0mm (MESHAKA et al., 1994), or oviductal eggs and enlarged yolked follicles (this report), the follicles can become atretic, and new follicles may be recruited from the ovarian germinal bed. Our data do not support the MeshaKa et al. (1994) high fertility theory for this invader gekkonid species. Nevertheless a $H$. mabouia population living in a temperate weather region from south of Brazil presented a seasonal reproductive period with females showing both oviductal eggs and vitellogenic follicles (BonfigLio et al., 2005). This study indicate a plasticity in reproductive strategy of this invader species living in an unfavourable environment since that closer of equatorial region the populations tend to present a year-round reproduction cicle (FITCH, 1970; VITT, 1986).

As in females, the males also presented a seasonal reproductive investment; during a period of year (between August 2002 and December 2002) we registered enlarged testis. The increase in testis volume, or size, does not necessarily denote sperm production, and this could be induced by an increase in the number of germinal bed cells (ShanbHag et al., 1998) or may indicate the overall effect of environment water availability on hydration of tissues (VITT, 1986). In tropical regions where temperature changes are less extreme than in temperate regions, rainfall and/or moisture may serve as an important environmental cue for gonadal recrudescence and breeding in reptiles (LOFTS, 1987; WHITTIER \& CREWS, 1987). In Valinhos the rainfall is markedly seasonal and the increase of testis volume seems to precede the increase in rainfall, thus the increase on testis volume can represents the increase on germinal beds number or even sperm production.

The mean size of hatchlings was $23.1 \pm 1.0 \mathrm{~mm}$, and the smallest newborn hatched in captivity measured $22.2 \mathrm{~mm}$. Field data showed that juveniles with body size close to that of newborns hatched at the laboratory occured in all months throughout the year, and this reinforces the idea of a continuous reproduction of the studied population.

Although this $H$. mabouia population studied presents a year-round reproduction, the climatic conditions during winter (dry season) in Valinhos could represent a limiting factor for newborns. Thus, the presence of both oviductal eggs and secondary vitellogenic follicles during a favorable season, summer (wet season), represent an efficient strategy of maternal investment to this "fixed" clutch sized lizard. Other important cue of maternal investment detected from this population was the larger and presumably older females producing larger eggs, which suggest that they are investing relatively more energy in reproduction than in body growth. Although there is some suggestion that the local environment of $H$. mabouia may affect the way the species will reproduce continuously or noncontinuously, it is possible that the seasonal increase on testis volume coupled with females clutches frequency increase (by both oviductal eggs and secondary vitellogenic follicles) during a favorable season may have favored the colonization and establishment of this exotic and invader gekkonid in Valinhos.

Acknowledgements. We thank people from Fazenda Manga for permit to work in the area of the farm, Vagner AriediJr. and Jivanildo P. Miranda for field assistantship on some occasions along the study, Paulo Joazeiro and Leonardo Yokoyama for assistance with preparation of histological sections and two anonimous reviwers for helpful comments. The study was supported by research grants from the Conselho Nacional de Desenvolvimento Científico e Tecnológico - CNPq to LAA (Process 130651/2002-8) and to CFDR (Processes \# 307653/ 2003-0 and \# 477981/2003-8). We also thank M.Van Sluys and D. Vrcibradic who kindly revised the manuscript offering helpful suggestions. 


\section{REFERENCES}

AndRews, R. M. \& RAND, A. S. 1974. Reproductive effort in anoline lizards. Ecology 55:1317-1327.

Blanco, G. M. \& Acosta, J. C. 1998. Ecología reproductiva de Teius oculatus em la provincia de Córdoba, Argentina. Bol. Soc. Biol. Concepción 69:33-38.

Bоск, B. C. 1996. Interclutch interval and egg aggregation in the tropical gecko, Hemidactylus mabouia. Herpetological Review 27(4): 181-183.

Bonfiglio, F.; Cappellari, L. H.; Balestrin, R. L.; Lema, T. 2005. Biologia reprodutiva de Hemidactylus mabouia (Moreaú de Jonnés, 1818) (Sauria: Gekkonidae) em área urbana de Porto Alegre, Rio Grande do Sul, Brasil. Comunicações do Museu de Ciências e Tecnologia da PUCRS, Sér. Zool., 18(1):13-20.

Butterfield, B. P.; Huge, B. \& Meshaka, W. E. 1993. The occurrence of Hemidactylus mabouia on the United States mainland. Herpetological Review 24(3):111-112.

Doughty, P. 1997. The effects of "fixed" clutch sizes on lizards" life histories: reproduction in the Australian velvet gecko, Oedura lesueurii. Journal of Herpetology 31(2):266-272.

Fitch, H. S. 1970. Reproductive cycles in lizars and snakes. University of Kansas Museum of Natural History, Misc. Public., 52:1-247.

Lawson, R; Frank, P. G. \& Martin, D. L. 1991. A gecko new to the United States Herpetofauna, with notes on geckoes of the Florida Keys. Herpetological Review 22(1):11-12.

Lofts, B. 1987. Testicular function. In: Norris, D. O. \& Jones, R. E. eds. Hormones and Reproduction in Fishes, Amphibians and Reptiles. New York, Plenum. 283-301p.

Meshaka, W. E. 1994. Reproductive cycle of the Indo-Pacific gecko, Hemidactylus garnotii, in south Florida. Florida Scientist 57(1-2):6-9.

2000. Colonization dynamics of two exotic geckos (Hemidactylus garnotii and H. mabouia) in Everglades National Park. Journal of Herpetology 34(1):163-168.

Meshaka, W. E.; Butterfield, B. P. \& Hauge, J. B. 1994. Reproductive notes on the introduced gecko Hemidactylus mabouia in southern Florida. Herpetological Natural History 2(1): 109-110.

Selcer, K. W. 1990. Egg-size relationship in a lizard with "fixed" clutch size: variation in a population of the Mediterranean gecko. Herpetologica 46(1):15-21.

Sexton, O. J. \& Turner, O. 1971. The reproductive cycle of a Neotropical lizard. Ecology 52:159-164.

Shanbahag, B. A; Subraya, L. \& Saidapur, S. K. 1998. Pattern of recruitment, growth of developing follicles, and germinal bed activity in the tropical gecko, Hemidactylus brooki. Journal of Herpetology 32(4):566-572.

Stamps, J. A. 1977. Social behavior and spacing patterns in lizards. In: Gans, C \& Tinkle, D. W. eds. Biology of the Reptilian. New York, Academic. v.7, p.265-334.

Trivers, R. L. 1972. Parental investment and sexual selection. In: Campbell, B. G. ed. Sexual Selection and the Descent of Man. Aldine, Chicago. p.136-139.

1976. Sexual selection and resource-accruing abilities in Anolis garmani. Evolution 30:253-269.

Van Sluys, M; Rocha, C. F. D \& Ribas, S. C. 1994. Nematodes infecting the lizard Tropidurus itambere in southeastern Brazil. Amphibia-Reptilia 15:405-408.

Vanzolini, P. E., Ramos-Costa, A. M. M. \& Vitt, L. J. 1980. Répteis das Caatingas. Rio de Janeiro, Academia Brasileira de Ciências. 161p.

VITT, L. J. 1986. Reproductive tactics of sympatric gekkonid lizards with a comment on the evolutionary and ecological consequences of invariant clutch size. Copeia (3):773-786.

WhitTier, J. M. \& CRews, D. 1987. Seasonal Reproduction: Patterns and Control. In: Norris, O. \& Jones, R. E. eds. Hormones and Reproduction in Fishes, Amphibians and Reptiles. New York, Plenum. p.283-301.

WhitTier, J. M. \& Limpus, D. 1996. Reproductive patterns of a biologically invasive species: the brown tree snake (Boiga irregularis) in eastern Australia. Journal of Zoology 238: 591-597.

Zar, J. 1999. Biostatistical Analyses. New Jersey, 4th ed. $663 p .+2 p p$.

Recebido em setembro de 2005. Aceito em julho de 2007. ISSN 0073-4721

Artigo disponível em: www.scielo.br/isz 